\title{
Mobbing and Harcèlement Moral in Comparative Perspective. Study of the Phenomenon in Poland and France.
}

\author{
Monika Budnik ${ }^{1}$ \\ 1 Higher Banking School of Wrocław, Department Management and Finance, Institute of Human Resources; \\ Fabryczna 29-31 street, postal code: 53-609 Wroclaw, Poland, e-mail:monika.budnik@wsb.wroclaw.pl \\ 2 University of Wroclaw, Department Social Science, Institute of Sociology, Poland; e-mail: \\ m.budnik@wns.uni.wroc.pl \\ * Correspondence: e-mail:monikabudnik@interia.pl; Tel.: +48600179817
}

\begin{abstract}
The topic of the article refers to expressions used to address the psychosocial risk linked to the workplace violence. The article bases on the Polish-French comparison, using analysis of definitions, legal acts and public statistics. The purpose is to show social differences, in the context of mobbing and "harcèlement moral", that surface from ratified definitions of these phenomena and public statistics. The final conclusions are the effect of a compilation of results of analysis and available literature. The choice of the two European, diverse areas of comparison for the diagnosis Poland and France - is the result of selection of the method of data content analysis, chosen by the author because of the availability of the scientific resources essential for the article and accessible during an academic stay in Centre d'Etudes de l'Emploi in France.
\end{abstract}

Keywords: Mobbing, Harcèlement moral, Workplace, Psychosocial risk, Content analysis.

\section{Introduction}

The topic of the article addresses the multicultural crucible of expressions, which are used to define phenomena of violence that represent psychosocial risks in the workplace.

By focusing on the concept of mobbing or "harcèlement moral", the author of the article points out a conceptual dispersion originated in national, local differences in both the extent of assimilation of anglicisms in the native language, as well as the categorization of the violence phenomena in the workplace. A supplement for these definitional analyses is the indication of legislative, official differences in the mobbing and "harcèlement moral" definitions in Poland and France. Explaining the concept of mobbing or "harcèlement » results in a specified valuation of these concepts and, consequently, in defining the phenomenon in the Labor Code and imposing sanctions. The definition of the concept, which is the core for evaluation of the repeatability of mobbing or "harcèlement moral" in the workplace, is a start of the cause and effect chain of providing evidence to the non-material, intangible psychological losses. Although this process socially 
teaches how to officially defend oneself in court, based on a history of previous cases, at the same time it reinforces the sophisticated forms of abuse - intangible to witnesses - associated with mobbing or "harcèlement in the workplace". The context of culture and legal norms is one of the areas that form social courage and condemnation of this phenomenon.

The other comparative picture presented here is the picture of the mobbing and "harcèlement" phenomena that emerges from the analysis of information available through the Polish and French public statistics. The author focuses the theoretical references to this comparative analysis on sociometry, with the indication of the key concepts that cohesively tie irrevocability of mobbing or harcèlement occurrence in teamwork, which was confirmed by (Faulx et Detroz,2009) in their post research findings. The picture of issues which are exhibited in statistics or which are not shown (also in topics such as health at work, psychosocial risks) creates a list of social issues either popular or ignored by public opinion. Measuring the frequency of events, setting standards and limits for health in the workplace is an area of institutional standards governing damage limit to health (Gollac and Volkoff 2007). In the European statistics (EUROSTAT), we can see the picture of «health at work» interpreted by indicators and values. In statistics, the image "safety and hygiene at work" fills in data: accidents at work, statistics on occupational diseases, subjective perception of working conditions are measured in a European opinion poll on occupational safety and health initiated by EU-OSHA (European Agency for Safety and Health at Work). The selection of research topics follows from European policy goals, set out in documents such as the European Security Strategy and Health at Work where one of the directions suggests an important social problem in the field of work "implementation of measures to promote a healthy environment and mental well-being at work $^{1 "}$.

In times of mobility and dynamic labor markets, the psychosocial risks that people are subjected to in the workplace are present both in European and local areas of employment. Those risks, however, adopt locally different definitions. The notions discussed in the article can be viewed from many theoretical perspectives.

Cultural socialization, together with a social learning process, is the reason that we form varied hierarchies of values or social problems. A given nation recognizes

\footnotetext{
${ }^{1}$ Communication from the Commission to The European Parliament, The Council, The European Economic and Social Committee and the Committee of the Regions on an EU Strategic Framework on Health and Safety at Work 2014-2020, Brussels 6.6.2014, COM 332, p.12, acces: http://eur-lex.europa.eu
} 
certain phenomena as important to be included in educational texts and, to other phenomena, gives its consent. Interesting here is a sociolinguistic process of appointing different codes to the same definitions which, in the theory of sociology, was recognized by as far back as (Bernstein 1971). In the theory of classic constructionism Berger or Luckmann, we have a perspective where concepts, notions are the products of collective negotiation of meanings. This subjectivity in how we create "the construct" in the social world also applies the concepts of health at work, suffering at work, the perception of the risks, benefits and loss in work from the worker's perspective. Nowadays either we give meaning to social issues or this meaning is created by the trade unions as a group for the formation of significant constructs - including concepts such as psychosocial risks. An article (Marc Loriol, 2015) refers to this phenomenon of how the notion is created and will be an impulsion for the worker to change their professional group. Not only does Loriol develop the notion of health at work in cases of stress at work but he also creates necessary implementation of a process of intervention at work - focused on the person - for an increased quality of work in the perspective of human relations. In this method, using mindfulness in the workplace helps to develop skills with more freedom from thinking patterns which are based on our dogma in work conflicts (Loriol, 2014). Also Loriol, as well as other authors, refers to the issue by setting a meaning of notion to terms such as "health at work" or "psychosocial risks" seen in statistics.

Trying to understand the risks from the perspective of the profession, must we mention the subjective perception of threat. In the longer term, a process of labelling and categorization is formed by employees, but they may feel fear before the schematic process of labelling at work also in the mental or emotional sphere. This issue refers to the trajectory of a career and illustrates the complexity of the problem and the way of recognition of the issues behind the problem. Fear before giving a negative role in the team is a form of hidden fears of lack of acceptance, fear before rejection out to the peripheral positions in the workplace. These definitions place different emphases on the role of the team and co-workers in the experience of workplace violence. The peculiarity of linguistic comparisons of definitions is not the only one, in the comparative view of psychosocial risks an employee may be subjected to. As noted by (Dressen 2011), violence in the workplace has its typologies, which can be seen both in the individual work and group work. Viewing a violence risk from the perspective of a type of work performed (individual or group) is one of the variables pointed out by (Dressen, 2011). A psychological violence which may be rooted in teamwork is reflected in 
"harcèlement moral", "harcèlement sexuel" and an obsessive degradation of an individual through persistent moral and physical dominance. The overall collations, made by the author, comparing the types of workplace violence with its source (individual or group work) and taking into account goals and instruments of the violence, all indicate that teamwork is more often a source of violence of various kinds. Thus, teamwork carries a bigger risk of violence in the workplace, particularly in the context of moral violence.

The experience of violence in the workplace is one of the many psychosocial risks. The violence can manifest itself in various, sophisticated forms of social oppression. One of them is a symbolic or psychological violence rooted in the fear of losing dominance. It also refers to the fear of losing occupational dominance. The relationship of dominance and violence was described in the sociological theory by (Bourdieu, 1977).

In team relationships, the fear of losing dominance can manifest itself in at least three ways. The first situation is when violence penetrates the team slowly, as described

(Dressen, 2011), "violence insidieuse" which involves repetitive slanders used by a group of employees in order to weaken the power of an individual in the collective.

Symbolic violence is most severely shown in the workplace communication. Recognized here is the communication in its passive and active form, which means that the violence is both the rumors or slanders about an individual, having a negative impact on the image of him or her, as well as an elimination of an individual from the communication. It is important to point that, particularly in the long term, one-sided interactions in a collective are the threat, because they can reinforce an individual's isolation or appoint a subordinate role in relationships which, according to the structure, should take place on a parallel level. A routine, in the face of prestigiously unequal tasks for same level positions, is an essential risk factor. A risk of an isolation from the communicative web is a possible direction of development of the team spirit. Teamwork is an area saturated with interactions. Simultaneously, this area implies the risk of mutual violence, which surfaces together with interactions of some people with the other in the course of professional work. Specifics of the phenomena's awkwardness, from the perspective of symbolic interactionism, comes from an individual's dilemmas about costs he or she will suffer depending on whether he or she will accept the role of a victim or will decide to stand up to the team's oppression. The costs, for an individual experiencing abuse, are emotional, psychological losses, together with 
the loss of dignity, autonomy or occupational status. With regards to the degradation of a professional status, the cost is also the risk of temporary or permanent professional inactivity, as the effect of entanglement in stress from experiencing the workplace violence. A non-material cost for somebody entangled in the experience of suffering at work is the loss of an occupational prestige, which, along with taking the case to court, may influence a subjective evaluation of trust of business partners, clients or potential employers towards the victim. Distressful is the very loss of a job that guaranteed financial stability.

As indicated above, a set of concepts surrounding this article would require the leading of the reader to the current number of perspectives from which we can look at the issue. Presented with references to subtle cross-linguistic differences in the first part of the paper, the reader should concentrate on an analysis of two national definitions of the psychosocial risks to which two expressions are linked, mobbing and harcèlement. Definition variations of the same phenomenon addressing the form of violence an individual may be subjected to in the workplace, are shown by the author by way of legal acts and literature. Moreover, presented here is a group of varied expressions, which appear in the English and French literature to address culturally diverse examples of experiencing the suffering in the workplace. The second part of this article refers to the statistic perspective which gives a view on the phenomenon of mobbing and harcèlement in the cases of France and Poland.

The choice of the two European, semantically diverse comparative areas for the diagnosis - Poland and France - was made because of the possibility to make comparisons with the use of the method of analysis of the information content accessible during the author's academic stay in the Centre d'Etudes de l'Emploi ${ }^{2}$ in France. The reader's interest in this essay is a form of an anti-mobbing activity through public attention what makes it possible to spread the concept of team violence in the context of sociology. Taking on this issue is essential for popularization of the holistic understanding of health and safety at work, which is the symbiosis of public, psychological and physical health.

${ }^{2}$ www.cee-recherche.fr 
6 of 25

\section{Conceptual differences - in the context of harcèlement moral and mobbing in the workplace}

The expression of mobbing was assimilated to the nomenclature of interpersonal relationships based on conclusions derived from an observation of behaviors of insects living in collectives (wasps, bees, termites, ants). More precisely, the behavior, that gave an origin to the meaning of the expression, refers to cases of attacking a specimen by a group of insects. The phenomenon was described, in the context of sociobiology, by the zoologist and ethologist Konrad Lorentz, whose book “On Aggression” was translated into English in 1967. The concept was adopted to workplace relationships in 1984 by a German psychiatrist Heinz Leymann (Leymann and Gustafsson, 1996), who used the expression to describe a psychological abuse directed toward chosen individuals of economic institutions. He defined the abuse as a hostile, unethical communication, directed in a systematic manner by a group toward one individual. Other synonyms used by Leymann to describe the phenomenon of workplace violence include words such as: harassment, undignified behaviors harming an individual's personality and psychological integrity. Apart from differences in the definition of this phenomenon, European methodology in social research uses a variety of research tools on the phenomenon of violence at work. The questionnaire which is repeatedly used in European research on violence in the workplace is a questionnaire called LIPT (Leyman Inventory Psychological Terrorisation) from 1990 (Leymann 1990). The second questionnaire is named Negative Acts Questionnaire- Revised (NAQ-R) (Einarsen et al. 2009). Research on mobbing was initiated in Sweden in times of the development of the industrial psychology. The Scandinavian observations, and then the British and American ones, initiated the interest in the mobbing phenomenon in other parts of Europe.

The set of concepts, which the reader of this article should become familiar with when diagnosing the subject of violence on the individual-group level, is a diverse area. The set of expressions describing the issue of an individual's suffering in the workplace, entails terminology which originated in different cultural contexts. Varied forms of violence in professional relationships are defined by expressions present in British literature: bullying, workplace bullying, harassment, sexual harassment. Adopted from the English language was the expression mobbing, which is being used in Europe to describe molestation, next to the French word harcèlement in France, we distinguish the expression harcèlement moral and harcèlement sexuel, while the second one is being used in the context of sexual discrimination in the workplace. 
In the British culture, among expressions describing violence that can take place between people on an occupational level is the expression bullying. This phenomenon is depicted as an aggressive intimidation, frequently used in the context of peer violence in relationships between youths in the British schools. A school class, from the sociometric perspective, is a group entangled in a system of statuses, roles and team issues common to the work teams. The phenomenon of bullying was described by synonymous expressions like terrorizing, intimidating, unjust treatment, verbal pressuring, insulting through: hurtful comments, rumors about an individual, biased assessments of performed tasks or reluctance to perform a task with an individual. In the context of occupational environment, the expression workplace bullying (Beale 2011) is used to describe aggressive intimidation, harassment, torment taking place between co-workers, as well as between managers and their subordinates, as stated in the definition:

Bullying may be carried out by managers and aimed at subordinates, it may occur between work colleagues (co worker bullying) or it may be a combination of both ${ }^{3}$.

Another expression for violence in the workplace is harassment (Einarsen et.al. 2009). Harassment, with the addition of the adjective sexual, gained particular significance. It is a sexual abuse, regardless whether it originates directly between co-workers or by way of new technologies (telephone, internet). The sexual harassment shows in verbal and non-verbal communication in the work team. More graphically, we talk about harassment when one individual's behavior violates an other individual's through suggestion of performing sexual acts, making sexual comments towards the individual. We deal with this behavior when one conditions a status in the work team on the basis of a degree of yielding to pressure, which means forcing an individual to surrender to the harassment. Achieving the victim's submission is the goal of the dominator or group of co-workers who harass.

The expression mobbing, used in the context of British and Scandinavian analyses of violence, stands out from the above expressions not only because of its different etymology. In the French literature, the phenomenon of molestation was named harcèlement and this local name has been adopted in the French judicial system.

The French concept harcèlement moral is seen as moral harassment and was used in 1998 by the French psychologist Marie France Hirigoyen (Hirigoyen, 1998). The fact, that the author introduced the expression to the discourse, does not mean

\footnotetext{
3 (Beale, 2011), p. 6.
} 
that the phenomenon of moral aggression between people had not existed in the workplace up until then. The motive of a possible experience of suffering of an individual in the workplace - in French souffrance au travail (Dejours and Begue,2009) was referred to in the literature on both sociology and psychology. Work can be a source of fulfillment of the needs for affiliation, contact with other people, exchange of information, acceptance and getting recognized for one's work, and, as written by $\mathrm{Ch}$. Dejours, work can both restore a person's dignity but also it can take it away.

Definitions of psychosocial risks gain a functional significance in the course of their being legitimized. The expressions used to describe a psychosocial risk like mobbing or harcèlements are being reinforced simultaneously with their implementation in the legal system. This area of functioning of the definition recognizes the significance of the very phenomenon, giving it an official dimension. This official presence of the phenomenon in the society is legitimized together with the imposing sanctions with regards to the compliance with labor laws against mobbing or harcèlements. In France, as well as in Poland, the precision for these official expressions for the psychosocial risks, like mobbing and harcèlements moral, is determined through the Labor Code and Penal Code. Cases of mobbing or harcèlements» are heard in Poland by departments of Labour Courts, in France by le conseil de prud'hommes. The differences between the Polish and French Labor Code in terms of the two expressions, despite current European guidelines, vary in terms of the types of imposed sanctions and the practice of jurisprudence. A great number of changes, requiring inclusion of the new definitions into European labour codes, are the effect of European directives, norms and guidelines ${ }^{4}$ aiming to standardize national versions of the labor law on European labor markets, however these changes are being implemented at different paces.

In the Polish Labor Code (Art. $94^{3} \S 2$.), the expression "mobbing" is defined as a phenomenon that involves:

actions or behavior toward an individual or directed against an individual,

\footnotetext{
${ }^{4}$ An example of such document is the Statement of the European Commission to the Council and the European Parliament containing a framework agreement on harassment and violence at work from 8 November 2007 KOM 2007/ 686) where it is stated that EU4 and national law define the employers' duty to protect workers against harassment and violence in the workplace. The document also declares that different forms of harassment and violence can affect workplaces and recognizes that harassment and violence can potentially affect work teams,p.6.
} 
involving harassment and intimidation of an individual, occurring on a frequent basis and over a very long time, resulting in decreased evaluation of professional capabilities, aiming to humiliate or ridicule an individual, isolate or force an individual out of the workplace.

The French Labor Code contains separate, whole chapters, devoted to both the phenomenon of harcèlements and discrimination in the workplace. It defines both harcèlement moral and harcèlement sexuel, including, apart from the definitions of the phenomena, the legal sanctions that are to be imposed.

Harcèlement moral is addressed in the French Labor Code (Title 5, chapter II, Article L1152-1 -L1152-65) as follows:

No employee should be subjected to repeated acts of harassment, which aim at, or result in a deterioration of working conditions, which can violate an employee's rights and dignity, have a negative effect on physical and psychological health or jeopardize his career.

The expression of harcèlement sexuel in the French Labor Code (Articles L1153-1 to L1153-6) is defined as:

directed toward an individual repeated comments or an undignified conduct of a sexual nature, that are offensive, humiliating, intimidating or create hostile and degrading situations.

The definition appeared in the Polish legal system in 2010, as the effect of the EU directives. In addressing the issue of mobbing in the workplace, the Polish Labor Code imposes two sanctions through civil proceedings. The first sanction, under Article $94^{3} \S 3$, is a monetary compensation for an individual for the loss of health as a consequence of mobbing, and the second sanction, under art. $94^{3} \S 4$, is a monetary compensation for termination of the employment contract as a consequence of mobbing in the workplace.

What is consistent for Polish and French labour court proceedings is the interpretation that the responsibility to maintain a workplace free from harassment lies with the employer. This employer's obligation is frequently the basis for appeal in lawsuits of moral harassment. As indicated by the decision of the courts in Poland and France, the defense of the employer must demonstrate that the 
10 of 25

indicators of moral harassment did not occur. It confirms the text of the French and Polish judgments:

French case ${ }^{6}$ :

when the employee establishes the materiality of the facts constituting precise and consistent proof of their harassment, it is for the court to assess whether these elements, taken together, allow a presumption of moral harassment and, if so, it is for the employer to prove that these acts do not amount to such harassment and that its decision is justified by objective elements in harassment.

The selection of this case shows the debatable (or subjective) justification between actors to the conflict in relation to the trajectory of long-term employment of employees in the commercial company. Indicators of harcèlement moral described in the judgment: dismissal with the short time of termination, changes in the organization of work, changing range of activities of work, changing superiors, ignored in communication, relationship problems in direct communication, directed to a visit to a doctor of occupational medicine.

In the Polish ${ }^{7}$ case, the indicators which had been mentioned in the judgment as mobbing were:

- Accusing the employee (the plaintiff) of a lack of skills, of conceptual thinking, of technical knowledge expertise, blaming her for mistakes not directly made by her.

- Several times, suggesting the employee the right to retire (the person being entitled to pension rights due to her age) at the same time highlighting her age and lack of fitness to work.

- Putting the pressure on the worker and creating an atmosphere causing her to perform her duties working in permanent stress, which ultimately caused the upset of her health, fainting twice during the operation, which resulted in the call for an ambulance to the workplace and the hospitalization of the employee,

- Forcing employees to repeat the same activities (preparing letters due to the use of

\footnotetext{
${ }^{6}$ The case comes: Cour de cassation, civile, 8 of june 2016, the reference number: $14-13418$, publié au bulletin access: https://www.legifrance.gouv.fr

${ }^{7}$ The case comes: District Court in Lodz, 25 of May 2016, the number of act VIII P 9/14, access: https://orzeczenia.ms.gov.pl
} 
the wrong fonts, incorrect drafting of the statement, the use of lowercase letters)

- Creating behaviors aimed at humiliating the employee (facial expressions, gestures, tone of voice)

- Discriminating the employee by directing comments about her person to the team behind her back

- Constantly criticizing the employee in the presence of co-workers

- Ridiculing the employee,

- Disregarding her work, turning it into derision among other employees, resulting in lowering of self-esteem and causing low opinion in the eyes of colleagues,

- Isolating her and eliminating her from the team

- Ignoring the worker in the implementation of new rules for pension benefits

- Not answering the employee's questions,

or with the comment that "the worker is making the same problems and difficulties"

- Organizing multiple meetings with the participation of colleagues, during which the employee was the only one not invited.

What is consistent in terms of the employer's obligations is the fact that the obligation to counteract mobbing in the Polish law lies on the employer. What distinguishes Polish law from the French attitude to arbitration is that the employee has to carry the burden of proof regarding the indication of circumstances that would justify a claim based on his/her allegations. A secondary rule in Polish law is the fact that the employer, to release from the liability for charges, tries to prove that these facts do not exist.

The differences that are seen in definitions of mobbing and harcèlement moral are noticeable in a number of areas. The first area regards the time in which a phenomenon must occur. This criteria is necessary to efficiently address the intangible, psychological losses of an individual during the court proceedings. Thus, an answer to the question of whether mobbing or harcèlement moral in the workplace occurred on a «frequent basis» or sustained over a long period of time is an essential determinant, with respect to the definitions of the expressions, distinguishing the phenomenon from an isolated incident of violence. That is why 
the court proceedings in cases of mobbing or harcèlement focus on proving that the phenomenon fits the officially legitimized definition in every aspect. The French definition, with regards to time, stresses that the acts of violence in the workplace must occur on a frequent basis in order to be able to call them harcèlements. The Polish Labor Code stresses that they must sustain "over a long period of time" to be able to conclude that the occurrence was mobbing. It should be mentioned that the Polish legal definition of mobbing determines the phenomenon as occurring over a long period of time, yet not indicating the time measure that specifies the long duration of the occurrence of mobbing. In these types of cases, this measure is determined according to the judiciary discretion. An analysis of court sentencing, however, is not the goal of this essay.

The Polish Labor Code provides a definition of mobbing with an indication of a number of different situations as examples of this phenomenon, including an important aspect of co-workers as a potential area for professional exclusion. The definition in the French Labor Code omits the work team as one of the areas of occurring harcèlement moral. The French definition addresses potential areas of losses caused by an experience of mobbing, such as: worsening of working conditions, worsening of mental and physical health, loss of dignity or professional future. All are presented in a calculated way, which indicates a complex approach to the degrading consequences of experiencing harcèlement moral in the workplace. In this definition, however, the role of co-workers is not stressed, contrarily to the Polish definition.

The forms of sanctions, that are catalogued in the French Penal Code (Code pénal, Article 222-33) for perpetrators of harcèlement moral, extend the Polish sanctions. They indicate the maximum fine of 30,000 EUR that may be imposed in cases of proven acts of harassment and up to two years of imprisonment.

The forms of sanctions, that are catalogued in the French Penal Code (Code pénal, Article 222-33), for perpetrators of harcèlement sexuel, also include the payment of a fine of up to 30,000 EUR in cases of proven acts of harassment and up to two years of imprisonment. In especially aggravating circumstances, the financial penalty may be increased to 45,000 EUR and three years of imprisonment (declared in Art. 222-33 of the French Penal Code).

According to the Polish Labor Code, an employer has a duty to counteract mobbing in the workplace, however it does not include methods of counteracting or diagnosing the phenomenon. It also does not include any sanctions for people 
engaging in mobbing in the workplace. Decisions with regard to a type of potential penalty is left to the Court's discretion. The practice of sentencing in Polish courts customarily shows an essential role of the individual, the plaintiff, to provide substantial evidence to the connection between the experienced mobbing and its effects on the individual's health.

Another area of comparison refers to diverse sanctions. The Polish judicial system does not specify a potential length of incarceration, nor the amount of potential monetary compensation in any schedule of charges. The French Labor Code categorically indicates the upper limit of a fine in the case of occurrence of harcèlement moral or harcèlement sexuel in the workplace.

Taking into account the role of the work team in the definition of this phenomenon appears to be very important in the context of proving that mobbing and «harcèlement» are significant risks for individuals in the work teams. In the courtroom, co-workers, as witnesses in a lawsuit, recreate the team fears, calculations and sociometric benefits. An interaction between a former employee (plaintiff), a former co-worker (witness), and the dominating role of an employer, who for the plaintiff means an occupational past and for the witness means an occupational present, constitutes a conflict that appears to be strongly rooted in the game of calculations and costs. In this game, the victim (plaintiff) of mobbing or harcèlement seems to be at a disadvantage, in the context of evidence, which mostly are testimonies of witnesses. As a result, the normative violence is a consequence of the symbolic violence, which is reflected in the victim's decreased chances of receiving help from the work team in collecting the evidence proving the acts of mobbing. Accordingly, the support is a utopia in a situation where the very team participates in the violence and the employer gives his or her consent to it, or in a situation where the team surrenders to an employer's pressure. 
14 of 25

\section{Public statistics in the case of mobbing - picture of the phenomenon in Poland and France}

The measurement of sensitive social issues would solely provide a deceptive picture of the phenomenon. Despite the calls for the scientific need for conducting research (Moreau and Dejours 2008) on the causes of the workplace violence, the examination of the issue in the psychosocial paradigm is fractional in the public area and is chiefly being undertaken by social sciences researchers. The research on working conditions is dominated by a paradigm in dealing with occupational health and safety, focusing on proven typologies, concepts and methods of measurement. In the context of psychosocial risks, public research favors a thematic approach focusing, at the most, on stress and methods of dealing with stress ${ }^{8}$ and methodological tools for measuring the costs of the psychosocial risks with regard to occupational diseases.

In its definition ${ }^{9}$, the continuous research on working conditions provided by the Polish employers entails only risks associated with harmful physical and biological working factors. The very definition of research on working conditions in Poland does not include psychosocial factors as important risks, what determines the elimination, from the nationwide research, of the diagnosis of psychosocial risks, including mobbing - an area of great importance in terms of an employee's health.

By analyzing the institutional data sources in Poland and France on the main topic of this analysis, we find the following data sources. The public statistics in France are in the possession of data regarding harcèlements, that is derived from the administration of justice and government research offices responsible for conducting surveys in the variety of thematic areas related to work. In Poland, the Ministry of Justice also publishes short information reports on its website.

In France, the aggregation of the statistic data was commended by the Ministry of Justice to the National Institute of Statistics and Economic Studies ${ }^{10}$ (INSE), in French: "Institut national de la statistique et des études économiques", which

\footnotetext{
${ }^{8}$ E-guide to managing stress and psychosocial risks, EU-OSHA national version polish, access http://osha.europa.eu

${ }^{9}$ Based on explanations of basic concepts of the survey by the Central Statistical Office (GUS) titled Working Conditions 2014, edition: Warszawa 2015, p.8, acces: http://stat.gov.pl

${ }^{10} \mathrm{http}: / /$ www.insee.fr
} 
enables an access to the non-confidential data by way of a significant, from the social sciences perspective, a portal called Quetelet network that shares results of public surveys carried out in France and addressing social issues such as the working conditions and psychosocial risks in the workplace.

In Poland, the very scope of data that is available about the phenomenon confirms that we can make deductions about social barriers in researching the phenomenon in the workplace only on the basis of formal statistics. The function of initiating research in this area was taken by the Central Institute for Labour Protection and the National Research Institute in Poland in the adjustment of working conditions in Poland to European Union standards. The aim of the project was to develop a questionnaire assessing occurrences of bullying ${ }^{11}$.

Having regard with the sentence above, the challenge toward social change, with regard to a greater awareness of psychosocial risks such as mobbing (this term functions in literature and statistics in Poland), could be achieved by trying to pilot the test and implementation of new tools in researching this phenomenon.

The trend of an increasing number of harcèlement court cases, that are brought to the Labor Courts in France, is confirmed by the ministerial data_from years 2012 and 2013. The Polish court statistics show that the number of lawsuits filed to pursue monetary compensation for termination of employment contract, as a result of being subject to mobbing, decreased by nearly 4\% between years 2012 and 2014.

The hypothesis about an increased awareness of employees in terms of capabilities of defending their rights in the Labor Court is confirmed by a larger number of cases in both France and Poland. The increase, in the years from 2012 to 2013, is by $14 \%$ in France. While, in the year 2014, in comparison with the number of new cases brought in the French Labour Courts in 2012, the increase in the number of cases is maintained at $7 \%{ }^{12}$. Unfortunately, the publicly available data regarding the activity of the Labor Courts does not include detailed information about the number of harcèlement moral cases tried in the French Labor Courts. The number of lawsuits in Poland shows, that in 2014 in over 477 of all mobbing lawsuits filed by employees in the Polish Regional Courts, 33 of them were entirely or partially settled by the Court. It represents nearly 7\% of all the lawsuits filed in 2014.

\footnotetext{
${ }^{11}$ http://www.ciop.pl

${ }^{12}$ Data addresses the Labor Courts activity - detailed data - for the whole France, in French: Activité des

conseils de prud'hommes - Données détaillées - Cumul France, access:

http://www.justice.gouv.fr/statistiques.html/statistique-judiciaire
} 
Annually, the average increase in the number of mobbing lawsuits heard and ruled favorably by the Polish Courts is nearly $3 \%$.

The source of data which are provided by the Polish Justice System is the very source that allows for the analysis of the social change with respect to mobbing on two issues. An increasing number of lawsuits addressing mobbing filed in the Labor Court is a testimony of greater legal awareness of employees. The second issue is an increased activity of women as plaintiffs in court cases pertaining to mobbing. It is supported also by a greater professional activity of the Polish women in the sector of customer service, and the customer service is the very type of teamwork with the more frequently occurring acts of mobbing.

Table 1 below shows the overall rise in lawsuits filed in Polish courts to seek compensations for the loss of health due to mobbing. Altogether, from the year 2012 to 2014 , we see an increase, of nearly $8 \%$, in the number of mobbing lawsuits filed in the Polish District Courts. Labor Departments of the Regional Courts in Poland are institutions of first instance, there are 138 of them in total.

Table 1. Number of lawsuits in the Polish courts, from 2012 to 2014, where courts partially or entirely ruled in favor of plaintiff seeking compensatory damages, based on health deterioration or employment termination caused by mobbing.

\begin{tabular}{|c|c|c|c|c|}
\hline number of & $\begin{array}{r}\text { Regional } \\
\text { ases ruled enti }\end{array}$ & $\begin{array}{l}\text { urts in } \\
\text { or pa }\end{array}$ & favor & \\
\hline in a given & aragraph by th & verall & legal & \\
\hline Year & & 2012 & 2013 & 2014 \\
\hline $\begin{array}{l}\text { compensation for } \\
\text { health }\end{array}$ & women & 11 & 9 & 20 \\
\hline $\begin{array}{l}\text { deterioration } \\
\text { caused by }\end{array}$ & men & 9 & 7 & 11 \\
\hline $\begin{array}{l}\text { mobbing } \\
\text { Art. } 94^{3} \S 3 \text { of } \\
\text { Labor Code }\end{array}$ & $\begin{array}{l}\text { Number of } \\
\text { all cases filed }\end{array}$ & 442 & 462 & 477 \\
\hline
\end{tabular}




\begin{tabular}{|c|c|c|c|c|}
\hline \multirow{4}{*}{$\begin{array}{l}\text { compensation for } \\
\text { employment } \\
\text { termination } \\
\text { caused by } \\
\text { mobbing } \\
\text { Art. } 94^{3} \S 4 \text { of } \\
\text { Labor Code }\end{array}$} & & 2012 & 2013 & 2014 \\
\hline & women & 1 & 5 & 8 \\
\hline & men & 1 & 4 & 2 \\
\hline & $\begin{array}{l}\text { Number of } \\
\text { all cases filed }\end{array}$ & 138 & 141 & 133 \\
\hline \multicolumn{5}{|c|}{$\begin{array}{c}\text { District Courts in Poland } \\
\text { number of cases ruled entirely or partially in favor of plaintiff }\end{array}$} \\
\hline \multicolumn{5}{|c|}{ in a given paragraph by the overall mobbing legal cases filed } \\
\hline \multicolumn{2}{|c|}{ Years } & 2012 & 2013 & 2014 \\
\hline \multirow{3}{*}{$\begin{array}{l}\text { compensation for } \\
\text { health } \\
\text { deterioration } \\
\text { caused by } \\
\text { mobbing } \\
\text { Art. } 94^{3} \S 3 \text { of } \\
\text { Labor Code }\end{array}$} & women & - & 3 & 3 \\
\hline & men & - & 1 & 1 \\
\hline & $\begin{array}{l}\text { Number of } \\
\text { all cases filed }\end{array}$ & 100 & 94 & 88 \\
\hline \multirow{3}{*}{$\begin{array}{l}\text { compensation for } \\
\text { employment } \\
\text { termination } \\
\text { caused by } \\
\text { mobbing } \\
\text { Art. } 94^{3} \S 4 \text { of } \\
\text { Labor Code }\end{array}$} & women & 1 & - & - \\
\hline & men & - & - & 1 \\
\hline & $\begin{array}{l}\text { Number of } \\
\text { all cases filed }\end{array}$ & 30 & 37 & 38 \\
\hline
\end{tabular}


The statistics presented here involve two possibilities of raising a claim that are allowed by the Polish Labor Code. First is the case of a lawsuit filed by an employee subjected to mobbing against an employer, seeking compensations for deterioration of health due to mobbing, and the second form, a lawsuit filed by an employee seeking monetary compensation for the termination of an employment contract if that employee has terminated his or her employment relationship as a result of being subject to mobbing.

In the Courts of Second Instance (District Courts), records show the opposite trend to the Regional Courts. The Labor Divisions of the District Courts addressing cases involving mobbing are second instance tribunals, overall in Poland there are $59^{13}$ of them. Since the year 2012, the Polish District Courts have recorded a decrease (by nearly 12\%) in all lawsuits filed to seek compensations for the loss of health due to mobbing, which signifies a low rate of appealing the original sentences. There has been an increase, by nearly a quarter since the year 2012, of lawsuits filed in the Polish District Courts to pursue monetary compensation for termination of an employment contract as a result of being subject to mobbing. In the context of gender, female employees, more often than male employees, raise legal claims related to the subject matter against their employers.

Important here is that a crucial condition, with regard to evidence in pursuing compensations for termination of employment contact due to mobbing in Poland, is an entry in the certificate of employment confirming that the termination of employment was in fact caused by mobbing. The dispute about the entry in the certificate of employment may cause a real conflict of interest between an employer and employee, because the reason for the employment termination is a key evidence in court cases regarding mobbing. Failure to consider an employee's request for alteration of the content of the certificate of employment, calls for an involvement of the State Labor Inspection in the dispute and initiates administrative proceedings with regards to the case. If an employee decides to take a dispute with his or her employer to court, in the mobbing cases the burden of proof is carried by the plaintiff, what in accordance with the Polish Civil Code's references to the Labor Code.

Table 1 shows, that the number of filed lawsuits alleging mobbing, together with rulings, is increasing. They are of educational value not only for attorneys, but also for their clients - the employees who are to compile admissible evidence in the

\footnotetext{
${ }^{13}$ Small Statistical Yearbook of Poland 2015, table 5 (43) data from 2014, p.81, access: http://stat.gov.pl
} 
mobbing court cases. The data with the number of mobbing lawsuits filed in Labor Courts provides a picture of a legitimate, official area of conflict between an employee and employer, although the very acts of violence may be carried out by co-workers symbolically. The symbolic violence refers also to the employer's consent to the acts of violence (psychological, physical, symbolic, normative, moral) together with which its insidious form, «violence insidieuse», is also a form of symbolic violence.

Data compiled based on records of legal cases in courts of first instance, seeking compensations for given types of discriminating acts in years 2009-2014, in accordance with the Informant of Justice Statistics www.isws.ms.gov.pl

Beyond the Ministry of Justice a second source of ministerial studies in France is the Ministry of Labour and Employment. There is a national survey of working conditions that has become a tradition from the year 1984. The research was then jointly conducted by the National Institute of Statistics and Economic Studies (INSE, Institute national de la statistique et des études économiques) and DARES, the Center for Research, Studies and statistics of the Ministry of Labor and Employment (Direction de l'Animation de la Recherche, des Études et des Statistiques, Ministère du Travail et de l'Emploi). It is a periodically conducted survey, what allows for modification of the questionnaire in the face of changing working conditions. The area of psychosocial risks is not constantly analyzed, it is a supplementary area, nevertheless; in its definition it is recognized as one of the factors influencing an individual's work. The questionnaire modified in 2005 and 2010 allowed workers on the French employment market to answer questions regarding violence in the workplace.

The questions, that the employees in France were asked 10 years ago during the survey, and which results are widely available, corresponded to the Eurostat survey and regarded verbal and physical aggression taking place in the workplace. Only $1.6 \%$ of the 17,615 employees that responded to the questions in the year 2010 admitted that they were subject to this type of violence frequently or everyday. Much more employees, $7.4 \%$, who participated in the survey in France in the year 2005 revealed they frequently or everyday were subjected to verbal violence ${ }^{14}$.

Furthermore, in the context of health and work, occasionally published were the results of the research on psychosocial risks commissioned by the Ministry of

\footnotetext{
14 Results of the survey Conditions du travail 2005, enquête compémentaire employ, access: http://www.cmh.ens.fr, http://bdq.reseau-quetelet.cnrs.fr
} 
Health and the Ministry of Labour in France. An example of such research is the publication regarding medical supervision of exposure to occupational risks (orig. Title: Surveillance médicale des expositions aux risques professionnels (SUMER) 2010, DARES - Direction de l'Animation de la Recherche, des Études et des Statistiques, Ministère du Travail et de l'Emploi 2010). Significant research, information and consulting activities are conducted by a non-profit organization of employers and employees, INRS ${ }^{15}$, operating since 1947 in France. The need of an update, in the public opinion, of information about still passive actions with regard to the minimization of losses caused by harcèlement moral and harcèlement sexual - its influence on an individual's life and professional position - rests upon the public sector of science and research.

Apart from the mobbing records kept by the Polish justice, the Main Statistical Office occasionally carries out surveys. Institutions of national and European statistics are the second source of data, both in France and Poland.

The diagnosis of the Main Statistical Office in Poland (GUS) was carried out based on the Labor Force Survey (BAEL) involving respondents as young as 15 years old, which is a methodology taking into account adolescent workers, who are a minority on the employment market. The results of the survey show, that in the context of psychosocial risks in Poland, the risk of violence, bullying or harassment constitutes $4 \%{ }^{16}$ of all types of risks in the workplace. The Main Labor Inspectorate in Poland publishes an annual report on the execution of its tasks. Such report is also annually prepared by the Regional Labor Inspectorates in Poland. The regional reports are forwarded both to the Main Labor Inspectorate and to a voivodeship marshal of a given region. The report of the State Labor Inspection in Poland from the year 2014 shows, that of all the cases reported to the Labor Inspectorates in Poland, the cases involving mobbing, harassment and discrimination constituted, in 2014 ${ }^{17}$, nearly $2 \%$.

The European surveys on working conditions, EWCS, carried out by EUROFUND

(European Foundation for the improvement of Living and Working Conditions ${ }^{18}$ )

\footnotetext{
${ }^{15} \mathrm{http}: / /$ www.inrs.fr

${ }^{16}$ Accidents at work and work related health problems, Central Statistical Office 2014, available, p.22, access: http://stat.gov.pl

${ }^{17}$ Data from the activity report of the State Labour Inspection in 2014, p.25, access: http://www.pip.gov.pl

${ }^{18}$ eurofound.europa.eu
} 
share a common area of research on the phenomena of «harcèlement moral» and mobbing (although the expression mobbing is used in the statistics of the European Union offices). The survey was conducted, for the sixth time in 2015, among the European employees of the EU member countries, however the results have not been fully published, yet. The results of the previous survey from 2010, which are published in full, make it possible to compare the results concerning working conditions in the EU countries. A random sample of employees in a given country is selected based on the employment data sent to the Statistical Office of the European Union.

In terms of mobbing as a psychosocial risk, the results of the European survey from 2010 allow to point, in the context of relationships with co-workers, to the following comparisons. Based on the answers below, and in the context of relationships with co-workers, which is essential when analyzing mobbing from the perspective of the work team sociometric status, one can say that:

- help and support received in the workplace from the work team, as declared by an individual, reaches a higher level among the French workers than Polish ones (difference at the level of $5 \%$ ),

- a similar result, with respect to the Polish and French employees, regards an aspect of recognizing supervisors as helpful,

- employees whose work involves intensive interactions (customer service occupations) are at a higher risk of mobbing or harcèlement than employees whose work requires greater level of autonomy (working alone)

Altogether, in Poland as well as France, the most often declared form (by both nations) of workplace violence is verbal abuse. The French employees reveal experiencing verbal abuse at a higher level (a difference of nearly 6\%). The French customer service employees particularly more often declare being subject to the verbal abuse. Also the French employees three times more often admit to being subject to threats in the workplace, and the customer service employees are more often exposed to threats than the industry employees. Likewise, the customer service employees of both countries more often reveal experiencing workplace harassment or bullying. These results confirm a common feature of the secondary survey's results, which is that a greater possibility of psychosocial risks runs among people working in customer services, where interpersonal relationships are polarized similarly to a work team. Detailed results are shown below. 
Table 2. Based on European Foundation for the improvement of Living and Working Conditions, EWCS 2010, access: eurofound.europa.eu

\begin{tabular}{|c|c|c|c|c|c|c|}
\hline \multirow{7}{*}{$\begin{array}{l}\text { Factor } \\
\text { Social } \\
\text { relationship }\end{array}$} & \multirow{4}{*}{\begin{tabular}{l}
\multicolumn{1}{|c}{ Questions } \\
Do your \\
colleagues help \\
and support \\
you?
\end{tabular}} & \multirow{4}{*}{$\begin{array}{l}\text { YEAR } \\
2010\end{array}$} & \multicolumn{2}{|c|}{ POLAND } & \multicolumn{2}{|c|}{ FRANCE } \\
\hline & & & Total & $62 \%$ & Total & $67 \%$ \\
\hline & & & Industry & $64 \%$ & Industry & $65,8 \%$ \\
\hline & & & Services & $61,9 \%$ & Services & $68,2 \%$ \\
\hline & \multirow{3}{*}{$\begin{array}{l}\text { Does your } \\
\text { manager help } \\
\text { and support } \\
\text { you? }\end{array}$} & \multirow[t]{3}{*}{2010} & Total & $53,1 \%$ & Total & $53,1 \%$ \\
\hline & & & Industry & $45,3 \%$ & Industry & $57,8 \%$ \\
\hline & & & Services & $52,3 \%$ & Services & $58,7 \%$ \\
\hline \multirow{10}{*}{$\begin{array}{c}\text { Factor } \\
\text { Violence and } \\
\text { harassment }\end{array}$} & Questions & YEAR & \multicolumn{2}{|c|}{ POLAND } & \multicolumn{2}{|c|}{ FRANCE } \\
\hline & \multirow{3}{*}{$\begin{array}{l}\text { Have you been } \\
\text { subject to } \\
\text { verbal abuse at } \\
\text { work in the } \\
\text { last month? }\end{array}$} & \multirow[t]{3}{*}{2010} & Total & $7,9 \%$ & Total & $14,5 \%$ \\
\hline & & & Industry & $3,8 \%$ & Industry & $8,2 \%$ \\
\hline & & & Services & $11,1 \%$ & Services & $16,6 \%$ \\
\hline & \multirow{3}{*}{$\begin{array}{l}\text { Have you been } \\
\text { subject to } \\
\text { threats and } \\
\text { humiliating } \\
\text { behaviour at } \\
\text { work in the } \\
\text { last month? }\end{array}$} & \multirow[t]{3}{*}{2010} & Total & $2,4 \%$ & Total & $7,1 \%$ \\
\hline & & & Industry & $1,2 \%$ & Industry & $3,6 \%$ \\
\hline & & & Services & $3,3 \%$ & Services & $8,2 \%$ \\
\hline & \multirow{3}{*}{$\begin{array}{l}\text { Have you been } \\
\text { subject to } \\
\text { physical } \\
\text { violence at } \\
\text { work in the } \\
\text { past year? }\end{array}$} & \multirow[t]{3}{*}{2010} & Total & $1,1 \%$ & Total & $3,8 \%$ \\
\hline & & & Industry & $1,8 \%$ & Industry & $0,8 \%$ \\
\hline & & & Services & $1,7 \%$ & Services & $4,8 \%$ \\
\hline
\end{tabular}


23 of 25

\begin{tabular}{|l|l|l|l|l|l|l|}
\hline & \multirow{2}{*}{$\begin{array}{l}\text { Have you been } \\
\text { subject to } \\
\text { bullying or } \\
\text { harassment at } \\
\text { work in the } \\
\text { past year? }\end{array}$} & 2010 & Total & $0,7 \%$ & Total & $9,5 \%$ \\
\cline { 2 - 6 } & Industry & $0,8 \%$ & Industry & $6,9 \%$ \\
\cline { 2 - 6 } & Services & $0,7 \%$ & Services & $10,4 \%$ \\
\hline
\end{tabular}

\section{Conclusion}

This article presents a comparison picture of the psychosocial risk linked to the problem which is defined in Poland as mobbing and in France as harcèlement moral. By doing the analysis, the author pointed to differences of legitimate, judicial definitions that are used to describe the same phenomenon in Poland and France. The definitions of the phenomena and the sanctions included in the European and local labor codes are simultaneously the framework for defense in disputes of this type. The author showed that there is a greater number of lawsuits addressing these issues heard and tried in the Courts in Poland and France. On the basis of this formal data, one can conclude there is a bigger social awareness and knowledge among employees, which correlates to a more intense activity in terms of filed lawsuits addressing experiences of mobbing and harcèlement moral. By using comparative sources, it was proved that, in the context of employment, violence in the workplace dominates the customer service sector and is more prevalent amongst people working in teams. How a given society defines the workplace psychosocial risks, like mobbing, harcèlement moral and harcèlement sexuel, corresponds to the social evaluation of the phenomenon of violence in the workplace. It is confirmed in the frequency and persistence of researches addressing the very issue, which is the subject of public surveys on a constant basis.

\section{References}

Bernstein, Basil. (1971) Class, Codes and Control. London: Routledge \& Kegan Paul Ltd, pp.130-132.

Beale, David. (2011) "Workplace bullying and the employment relationship, exploring questions of prevention, control and context". Work Employment $\mathcal{E}$ Society 25 (1):5-18.

Bourdieu, Pierre. (1977) "Sur le pouvoir symbolique". Annales Économies, Sociétes, Civilisations, 32(3):405-411. 
Dejours, Christophe and Bègue Florence. (2009) Suicide et travail: que faire? Souffrance et théorie. Presses Universitaires de France.

Dressen, Marie (2011). Violences dans le travail, esquisse d'une typologie, dans Dressen Marie and Durand, Jean-Pierre (eds). La violence au travail, collection: Le travail en débats, série colloques et congrès. Toulouse, Octarès, pp.373-380.

Durkheim, Émile (1902-1903). L' éducation morale; cours de sociologie dispense à la Sorbone. Available at :

www.classiques.uqac.ca/classiques/Durkheim_emile/education_morale/education_ morale.pdf (accessed: 20 january 2016).Document, produced in digital version by Jean-Marie Tremblay in cooperation with the Quebec University Library of Paul-Émile-Boulet), p.32.

Einarsen, Ståle and Hoel, Helge and Notelaers, Guy (2009). "Measuring exposure to bullying and harassment at work: Validity, factor structure and psychometric properties of the Negative Acts Questionnaire-Revised". Work \& Stress 23 (1): 24-44.

Elias, Norbert (1976). "Sport et violence". Actes de la recherche en sciences sociales, 2 (6): $2-21$.

Faulx, Daniel and Detroz, Pierre (2009). "Harcèlement psychologique au travail:processus relationnels et profils de victimes. Approche processuelle, intégrative et dynamique d'un phénomène complexe". Travail humain 72 (2): 155-184.

Gollac, Michael and Volkoff, Serge (2007). Les conditions de travail, La Découverte, Paris.

Hirigoyen, Marie France (1998). Le harcèlement moral. La Découverte, Paris.

Karik Türkan and Yildiz, Süleyman Murat (2015). "The effect of mobbing behaviors on burnout of women's basketball players". International Journal of Human Sciences, 12: (2).

Lewin, Kurt and Lippitt, Ronald and White, Ralph (1939). "Patterns of aggressive behavior in experimentally created social climates". Journal of Social Psychology,10: 271-299.

Leymann, Heinz and Gustafsson, Annelie (1996). "Mobbing at work and the development of post-traumatic stress disorders". European Journal of Work and Organizational Psychology, 5 (2): 251-275. 
Loriol, Mark (2014). "Approches constructivistes des RPS" in Zawieja Philippe, Guarnieri Franck (eds.) . Paris, pp. 52-55.

Loriol, Mark (2015). "La souffrance au travail: Construction de la catégorie et mise en forme de l'expérience". Pensée Plurielle 38 (1):23-33.

Moreau, Valérie and Dejours, Christophe (2008). "Conjurer la violence. Travail, violence et santé. L'orientation scolaire et professionnelle". Institut national d'étude du travail et d'orientation professionelle, Paris 37(4): 573-574. 